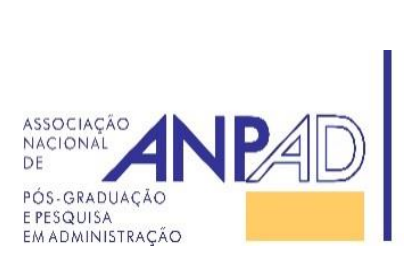
Available online at
http://www.anpad.org.br/bar
BAR, Rio de Janeiro, RJ, Brazil, v. 15, n. 4, art. 2, e170137, 2018
http://dx.doi.org/10.1590/1807-7692bar2018170137

\title{
The career advancement challenge faced by female executives in Peruvian organisations
}

Kety Jáuregui ${ }^{1}$

Mariella Olivos ${ }^{1}$

Universidad ESAN, Lima, Peru ${ }^{1}$

Received 7 November 2017. This paper has been with the authors for one revision. Accepted 13 November 2018. First published online 4 December 2018.

Editor's note. Ana Sílvia Rocha Ipiranga served as Associate editor for this article. 


\begin{abstract}
The percentage of women in Peru's workforce overall has been growing at a steady rate, but there are still few women are seen in executive positions. This qualitative study describes the challenges in women's professional career advancement in a country in which the cultural pattern of business is dominated by men and where specific roles have been assigned to women. In-depth interviews were conducted with 24 professionals, 11 women and 13 men. The interviews were analysed using qualitative data analysis software. The results show that family responsibilities were the main challenge for female executives' career advancement. Moreover, family responsibilities were linked to other challenges, such as physical mobility, educational attainment, professional experience and informal networks. Family responsibilities can be considered a transcultural challenge to the career advancement of female executives. Finally, the study shows that a country's culture is an important challenge to career advancement, as in the Peruvian context where women are still considered responsible for attending to the family and are assigned a fundamental role in raising the children.
\end{abstract}

Key words: career advancement; executive women; Peru. 


\section{Introduction}

The financial condition of Western women underwent major changes during the $20^{\text {th }}$ century. While their entry into the labour market was initially limited to poorly paid occupations with few prospects, this situation has progressively improved in such a way that women have become an important part of the workforce.

According to Mainiero and Sullivan (2005), throughout women's lives, they change their career pattern according to the priority given to different aspects of their lives as they attempt to conciliate their roles in new ways. Specifically, O'Neil and Bilimoria (2005) show that family responsibilities may impact women's career development, while other scholars have identified challenges like education (Ragins \& Sundstrom, 1989), social capital or informal networks (Eagly \& Carli, 2007) and gender discrimination (Festing, Kornau, \& Schäfer, 2015; Lyonette \& Crompton, 2008; Still \& Timms, 1998; Tharenou, 1997). At the same time, some organisational cultures perceive women as less committed to their careers, and this also limits women's opportunities for promotion (Tharenou, Latimer, \& Conroy, 1994). It also must be borne in mind that a country's cultural values influence the culture of any given organisation in that country and, therefore, women's careers in that organisation (Khapova, Brisoce, \& Dickman, 2016).

In order to understand this situation, the study objective is to identify the challenges female executives in Peru perceive to their career advancement in organisations. This study begins with a review of the literature on career models and the challenges women face to their career advancement. Next, we described the methods and data used in the study, followed by the findings and discussion and conclusions. Finally, the study's limitations are considered and areas for future research are suggested.

\section{Literature Review}

A career is a person's developmental process over the course of his or her life. Organisations give career opportunities to their workers so their workers can grow professionally, which allows them to move vertically, horizontally or linearly and thus advance in their careers, occupying a series of positions at work. Career advancement is understood as promotion to higher levels in the organisational hierarchy or to positions with greater responsibility (Hall, 2002) A person can decide on a career path inside of an organisation, outside of the organisation or in a new business as an entrepreneur, depending on that person's career objectives (Baruch, 2004).

Career models have been evolving from models in which career paths are very linear to more dynamic models. Traditional career models like those of Hall and Schein are characterized by their high levels of structure and rigidity, linking professional success to upward movement and to external factors of success like salary and social status (Baruch, 2004). Hall (1976) suggested a linear trajectory, while Schein (1978) considered a trajectory which included vertical, horizontal and diagonal movements. The traditional models categorise professional development by age (Duberley, Carmichael, \& Szmigin, 2014), in a tiered progression, with linear promotion and uninterrupted, full-time employment (Herman, 2015; Kumra \& Vinnicombe, 2008). However, these models are criticised since they do not necessarily conform to the expectations and demands placed upon women (Evetts, 2000; Herman, 2015). Women know that if they want to belong to the labour market, they must adapt to a world created by and for men (Kumra \& Vinnicombe, 2010). This means they must work long hours at full-time employment (Warren \& Walters, 1998), in addition to being technically outstanding.

Eagly and Carli (2007) indicate that female executives encounter many diverse, complex challenges not organised along a linear path but rather forming a tangled labyrinth. Obviously, it can be supposed that a change in perspective of the conception and management of women's careers is necessary; new approaches that help to better explain women's careers leading up to the director and 
executive level must be sought out. In this sense, modern career models are characterized by discontinuity and nonlinearity (Duberley et al., 2014). Among these models are the protean career (Hall \& Moss, 1999), the kaleidoscope career (Mainiero \& Sullivan, 2005) and the boundaryless career (Defillippi \& Arthur, 1994). Betz and Fitzgerald (1987) and Evetts (2000) note that women's careers respond to their personal experiences and unique perspectives on life. Indeed, in these models there has been a shift from an organisation-focused perspective to a person-focused perspective.

Without any question, women's careers are unique and dynamic, not only involving their occupations but also their post-vocational interests, as well as their ability to integrate their personal and working lives. In this sense, O'Neil and Bilimoria (2005), considering the various moments in a woman's life, define a three-phase career model. The first stage, between 24 and 35 years of age, is called the idealist phase, since women base their professional choices on their desire to obtain professional satisfaction, achievements and success, and they focus on generating benefits for those around them. Stage 2, between 36 and 45 years of age, is called the resistance, because it corresponds to the period in which women have to intensely wrestle with the management of a family as well as work commitments. They must act pragmatically in response to operative demands, doing what they need to do. Stage 3, from age 46 on, called the reinvention stage, is the stage in which women orient themselves to contribute to their surroundings (organisational, family and community). In contrast, the stages of traditional career models describe (and generalise) the masculine experience in the work world (Mavin, 2001), which is why the contribution of O'Neil and Bilimoria (2005) sets out stages that follow the life experiences of women and the peculiar facets of their lives.

However, these new career models also have limitations, especially due to the cultural context in which they were developed. The national cultural context and the strength of the societal environment can also be expressed in terms of direct or indirect discrimination (Baruch \& Reis, 2015), masculinity and informality, among others. For example, Pringle and Mallon (2003) mention that in collectivist cultures, one's career is not exactly one's priority for the women.

Despite the appearance of these new models, the traditional career models continue to be the most commonly used in organisations (Baruch, 2006; Baruch \& Reis, 2015; Broadbridge, 2015). Consequently, women find career advancement challenging if they adopt the conventional, vertical career paradigm.

The achievement of a family-work balance is probably the most recognised career challenge for women (Kelly, Ammons, Chermack, \& Moen, 2010; Lyonette \& Crompton, 2008; Metz, 2005; Still \& Timms, 1998; Stone, 2007). Notably, one of the most criticised topics related to the needs of the female executive is that women have greater familial responsibilities than men do (Lyonette \& Crompton, 2008; O'Neil \& Bilimoria, 2005), which can reduce their educational and professional opportunities (Bass, 2015). For example, regarding career internationalisation, men tend to be the majority of those chosen to become company-assigned expatriates (Vance \& McNulty, 2014). In fact, Brookfield Global Relocation Services (2016) has found that only $25 \%$ of executives chosen for international assignments are women. Indeed, women often make career decisions based in large part on family necessities (Mainiero \& Sullivan, 2005), and this influences whether or not they continue at their workplace (Duberley et al., 2014) and therefore whether or not a linear career model can be followed; in many cases, it cannot be maintained. Given this situation, the family of a female executive with children is a valuable source of help for domestic chores and childcare, even more so in collectivistic societies, in which the proximity of family provides support networks. Also, their support can be expressed emotionally, which is especially important for women who have partners who encourage them to continue developing their careers (Cheung \& Halpern, 2010).

Educational attainment is an important requirement for executive management positions (Tharenou, 1997), due to the fact that it defines the intellectual abilities and competences that employees must possess in order to adequately perform in this kind of job. However, women tend to have fewer opportunities for educational attainment (Joshi, Neely, Emrich, Griffiths, \& George, 2015), including fewer training possibilities during their professional practice (Cheung \& Halpern, 2010; Morley, 2014). Due to this lack of education and work training, women also have fewer opportunities to access relevant 
work experience (De Pater, Van Vianen, \& Bechtoldt, 2010; Joshi et al., 2015). Even worse, in the few opportunities for education that women have via postgraduate management education, the gender perspective at business school is very limited. Heller (2011) maintains that most MBA students see the masculine management model as the only model in existence, as something which is normal in business management.

Social capital or informal networks also affect employability in executive and managerial positions (Broadbridge, 2008; O’Neil, Hopkins, \& Sullivan, 2011; Ragins \& Sundstrom, 1989; Tharenou, 1997), since through them, it can be deduced how sociable the candidate is. Indeed, social capital is more essential to managers' advancement than technical knowledge is (Eagly \& Carli, 2007). Women tend not to be involved in these networks, though, creating what could be interpreted as a barrier to promotion (Wirth, 2001). Ibarra (1992) identifies that while men tend to create more uniform networks in terms of gender (i.e., more men and fewer women), women tend to establish more diverse and heterogeneous networks, which, nonetheless, do not help them achieve promotions.

Another topic discussed in the literature is organisational culture (Acker, 2006; Broadbridge, 2008; Kelly et al., 2010; Ragins \& Sundstrom, 1989; Still \& Timms, 1998). Gender stereotypes and male values and patterns largely dominate organisational cultures (Broadbridge, 2008; Greenhaus \& Parasuraman, 1993; Joshi et al., 2015; Lyonette \& Crompton, 2008; Marshall, 1995; Ragins \& Sundstrom, 1989). Due to the effect of these stereotypes, many people still believe that most good managers are male (Powell, Butterfield, \& Parent, 2002). Cabrera (2007), reviewing numerous studies, points out that the traditional organisational culture is male, characterised by a mutual, high sense of competence among the members of the organisation. Additional male characteristics of the traditional organisational culture, Cabrera (2007) mentions, are a zero-sum perspective, power and hierarchical relationships in which managerial decisions are based on the masculine values of rationality, orderliness and conformity to authority. Ragins and Sundstrom (1989) indicate that women tend to have less power than men in organisations, one reason being the stereotypes regarding their managerial skills. Female characteristics and skills are unappreciated and frowned upon by many organisations (Kumra \& Vinnicombe, 2008). Furthermore, talent is frequently defined as a pattern of behaviour associated with male characteristics, for example, assertiveness and competitiveness (Festing et al., 2015).

From all of this, we can deduce that the limitations for the work development of women are due more to the gender bias existing in their work environments (Kumra \& Vinnicombe, 2008) and to the cultural context of their country, which is where some stereotypes originate. In Mexico, only $13 \%$ of companies have at least one woman in a director-level position, and a woman is the CEO in only $0.9 \%$ of companies (Zabludovsky, 2007). In Argentina, the organisational model is conceived and designed to attract male talent more than female talent for management positions, and the perception that there are jobs for women which are more affiliative and social than men's jobs is very ingrained (Heller, 2011). In Brazil a similar scenario is being played out: few management positions are held by women; however, some women believe that the barriers to executive-level career advancement are nonexistent (Mota-Santos, Tanure, \& Carvalho, 2014).

In the end, national culture impacts all behaviour in a society. The expectations regarding roles, norms and values associated with the social behaviour of men and women are based on national context (Unite, Parry, Briscoe, \& Chudzikowski, 2016). These expectations impact career experience and the form in which it is conceived (Khapova et al., 2016).

\section{Research Context: Peru and the Female Executive}

Peru is one of the fastest-growing economies in Latin America (World Bank, 2018). The presence of women in the labour market has evolved so that women's participation in the economically active population, increased from 20.3\% in 1972 (Instituto Nacional de Estadística e Informática [INEI], 1972) to $43.8 \%$ by the year 2016 (INEI, 2017a). In 2008, 22.7\% of management positions, from supervisors 
and coordinators to upper-level management, were occupied by women, and, by 2014, that percentage had grown to 30.8\% (INEI, 2015a). According to numbers from the Lima Stock Exchange in 2017 (Andina Agencia Peruana de Noticias, 2018), of the total number of registered businesses, $32 \%$ have at least one woman on the board of directors but none has more than three. Only $3 \%$ of registered businesses have a woman as the president of the board of directors, and only $4 \%$ have a female CEO. Thus, although in Peru the presence of women in positions of leadership has grown, the presence of women in upper management and critical decision-making positions is still very small.

It is important to mention at this point that for women to reach upper management and decisionmaking positions, it is essential for them to obtain experience in the management of operations, finance, sales, product research and development or general management functions, but the positions that women occupy are usually in fields such as human resources, public relations, communications, and administration, which limits their ability to move up (International Labour Organization [ILO], 2015).

The level of university education among Peruvian women has increased from $12.9 \%$ in 2004 to $15.9 \%$ in 2014 (INEI, 2015b). However, the percentage of university graduates who are women (48\%) is still slightly lower than that of men (52\%), and this difference only widens when describing those who hold doctoral degrees ( $40.1 \%$ versus $59.9 \%$, respectively).

Peru was ranked eightieth out of 144 countries in terms of gender equality in 2016 (World Economic Forum, 2016). This inequality can be seen in the difference of income for men and for women, as women earn only about two-thirds of what men earn for the same or similar jobs (INEI, 2017b; Ministerio de Trabajo y Promoción del Empleo [MTPE], n.d.a). This percentage is slightly better for women in white-collar professions. In this sense, women with university degrees earn slightly more than 70\% (71\%-73\%) of what men with the same degree earn (INEI, 2017b; MTPE, n.d.b).

Women's educational level (Blondet \& Montero, 1994; MTPE, 2006) has been a factor which has propelled the presence of women in the labour market. However, it has also been a factor correlated with a lower total fertility rate in Peru, from 4.3 children per woman in 1986-1987 to 2.5 children per woman for 2015-2016 (INEI, 2016). Moreover, women with higher education currently have 2.1 children on average, while those with lower levels of education tend to have more children. Indeed, it has been the trend for Peruvian women to have fewer children and more space between their pregnancies. In this sense, according to the sample of the Demographic Survey of Family Health in 2016, more than half of women $(59.7 \%)$ currently married or living with a partner desire to not have any more children (INEI, 2016).

In the average Peruvian household, the mother is in charge of taking care of the home (INEI, 2011). Even though both men and women participate in household chores, more chores are carried out by women than by men, especially those related to cooking, cleaning, shopping, washing, and taking care of the sick. The same can be seen regarding childcare. Indeed, the time that Peruvian women dedicate to childcare is, on average, 12 hours and 14 minutes every week and in large part consists of feeding and caretaking, in comparison with 5 hours and 49 minutes for men, which consists mostly of playing with the children (INEI, 2011). However, there are intra-gender differences regarding this issue between women of varying income and educational levels. The higher the income and level of education, the less time women give to unpaid household chores (Freyre \& López, 2011; INEI, 2011), as these women tend to hire domestic help (Kogan, Fuchs, \& Lay, 2013).

These data show that Peruvian women live in a markedly conventional society with deeply-held beliefs regarding the supreme value of the family and gender stereotypes in which men hold a dominant role in comparison to women.

Regarding the development of social capital, Wirth's study (2001) found that women executives tend to establish fewer and smaller networks of contacts than men do, due to their family responsibilities. Given this situation, one option would be to use virtual networks to develop social capital. Even so, as $72.4 \%$ of men in Peru use the Internet on a daily basis, while only $69.5 \%$ of women do the same (INEI, 2017b), there could even be a slight difference in developing social capital online. 


\section{Methods and Data}

\section{Data collection}

In this qualitative and descriptive study, we conducted 24 interviews, 11 with women and 13 with men. To select the interviewees, criterion-based selection (LeCompte \& Schensul, 2010) was implemented. This consisted of identifying which attributes of the sample were crucial for the purpose of the study.

The criterion-based selection had two phases. First, business and industry-specific periodicals were reviewed to identify both men and women who had been interviewed by the press due to their outstanding professional development. After compiling a list of possible interview candidates, the executives' labour history on LinkedIn was reviewed in order to evaluate whether they passed the other two filters: that they worked for large national and international organisations and that they possessed decision-making positions in their organisations. An additional criterion for male interviewees was that they had a family, in order to study their family responsibilities and their wives' or partners' family responsibilities, in keeping with the study's focus on female career advancement.

As a result of the application of the above-mentioned filters, 50 interviewees, both men and women, were selected, but only 24 of them accepted. The interviewees were executives in a variety of different industries, including banking, telecommunications, technology, energy, mining, retail, health, consultancy, education and food production. They also held diverse occupations (e.g., human resources, marketing, operations, finance and information technology) and varied in terms of educational background and marital status. All of them were actively employed at the time of the study. The majority possessed master's degrees. Table 1 provides a summary of the women's profiles. Details on the men's profiles are shown in Table 2.

Table 1

Women Interviewed

\begin{tabular}{|c|c|c|c|c|}
\hline Education & $\begin{array}{l}\text { Current } \\
\text { Position }\end{array}$ & Summary Career Trajectory & $\begin{array}{l}\text { Left original } \\
\text { sector to go into a } \\
\text { more flexible } \\
\text { one? }\end{array}$ & $\begin{array}{l}\text { Number of } \\
\text { children }\end{array}$ \\
\hline \multirow[b]{2}{*}{ MBA } & \multirow[b]{2}{*}{ Professor and director } & $\begin{array}{l}\text {-Human resources manager for a beer } \\
\text { company. }\end{array}$ & \multirow[b]{2}{*}{ Yes } & \multirow[b]{2}{*}{2} \\
\hline & & $\begin{array}{l}\text {-Global compensation and benefits } \\
\text { manager for a centre for food safety } \\
\text { research }\end{array}$ & & \\
\hline \multirow{2}{*}{ MBA } & \multirow{2}{*}{ Consulting manager } & $\begin{array}{l}\text {-Human resources manager for a } \\
\text { manufacturing company }\end{array}$ & \multirow{2}{*}{ Yes } & \multirow{2}{*}{1} \\
\hline & & $\begin{array}{l}\text {-Human resources manager for a } \\
\text { hospital }\end{array}$ & & \\
\hline MBA & Vice rector & $\begin{array}{l}\text {-Marketing director for the Andean } \\
\text { region }\end{array}$ & Yes & 1 \\
\hline
\end{tabular}

Continues 
Table 1 (continued)

\begin{tabular}{|c|c|c|c|c|}
\hline Education & $\begin{array}{l}\text { Current } \\
\text { Position }\end{array}$ & Summary Career Trajectory & $\begin{array}{l}\text { Left original } \\
\text { sector to go into a } \\
\text { more flexible } \\
\text { one? }\end{array}$ & $\begin{array}{l}\text { Number of } \\
\text { children }\end{array}$ \\
\hline $\begin{array}{l}\text { Psychology } \\
\text { (Bachelor } \\
\text { degree) }\end{array}$ & $\begin{array}{c}\text { Human resources } \\
\text { manager }\end{array}$ & $\begin{array}{l}\text {-Human resources manager for a } \\
\text { telecommunications company } \\
\text {-Human resources analyst for a } \\
\text { telecommunications company }\end{array}$ & Yes & 1 \\
\hline MBA & $\begin{array}{l}\text { Andean region } \\
\text { commercial director }\end{array}$ & $\begin{array}{l}\text {-Public sector commercial director } \\
\text {-Corporate accounts director for a } \\
\text { technology company } \\
\text {-Country manager for a technology } \\
\text { company }\end{array}$ & No & 3 \\
\hline $\begin{array}{l}\text { Master's in } \\
\text { human } \\
\text { resources }\end{array}$ & $\begin{array}{l}\text { Human resources } \\
\text { director }\end{array}$ & $\begin{array}{l}\text {-Human resources manager for a } \\
\text { fishing company } \\
\text {-Corporate human resources manager } \\
\text { for a food services company } \\
\text {-Human talent manager for a retail } \\
\text { company }\end{array}$ & Yes & 2 \\
\hline MBA & $\begin{array}{l}\text { Marketing } \\
\text { director }\end{array}$ & $\begin{array}{l}\text {-Brand manager for a manufacturing } \\
\text { company } \\
\text {-Operations control director of } \\
\text { another manufacturing company }\end{array}$ & No & $\begin{array}{l}\text { Single, no } \\
\text { children }\end{array}$ \\
\hline $\begin{array}{l}\text { Accounting } \\
\text { (Bachelor } \\
\text { degree) }\end{array}$ & $\begin{array}{l}\text { Administrator \& } \\
\text { control manager }\end{array}$ & $\begin{array}{l}\text {-Accounting manager for an electric } \\
\text { company } \\
\text {-Public company auditor }\end{array}$ & Yes & 3 \\
\hline MBA & $\begin{array}{l}\text { Chief information } \\
\text { officer }\end{array}$ & $\begin{array}{l}\text {-Senior information systems auditor } \\
\text { for a bank } \\
\text {-Enterprise risk manager for a } \\
\text { consulting company }\end{array}$ & No & $\begin{array}{l}\text { Single, no } \\
\text { children }\end{array}$ \\
\hline $\begin{array}{l}\text { Master's in } \\
\text { marketing } \\
\text { and } \\
\text { commercial } \\
\text { management }\end{array}$ & $\begin{array}{l}\text { Marketing } \\
\text { manager }\end{array}$ & $\begin{array}{l}\text {-Channel manager for a bank } \\
\text {-Marketing manager for a micro- } \\
\text { financing institution }\end{array}$ & No & $\begin{array}{l}\text { Single, no } \\
\text { children }\end{array}$ \\
\hline $\begin{array}{l}\text { Master's in } \\
\text { finance }\end{array}$ & Chief financial officer & $\begin{array}{l}\text {-Chief accountant for a retail } \\
\text { company } \\
\text {-Accountant-general for a retail } \\
\text { company }\end{array}$ & No & 2 \\
\hline
\end{tabular}

Note. Source: Elaborated by the authors. 
Table 2

Men Interviewed

\begin{tabular}{|c|c|c|c|}
\hline Education & Current position & Industry & $\begin{array}{l}\text { Number of } \\
\text { children }\end{array}$ \\
\hline $\begin{array}{l}\text { Master's in human } \\
\text { resources }\end{array}$ & Consulting manager & Consultancy & 3 \\
\hline MBA & CEO & Banking & 2 \\
\hline MBA & Country manager & Consultancy & 3 \\
\hline MBA & Dean & Education & 3 \\
\hline $\begin{array}{l}\text { Business administration } \\
\text { and postgraduate in } \\
\text { management studies }\end{array}$ & $\begin{array}{c}\text { Human resources } \\
\text { management vice-president }\end{array}$ & Banking & 2 \\
\hline MBA & $\begin{array}{l}\text { Marketing and sale vice- } \\
\text { president }\end{array}$ & Telecommunications & 3 \\
\hline MBA & CEO & Technology & 4 \\
\hline $\begin{array}{l}\text { Master's in agro- } \\
\text { industrial administration }\end{array}$ & $\begin{array}{l}\text { International food industry } \\
\text { manager }\end{array}$ & Food Industry & 2 \\
\hline MBA & Distribution manager & Energy & 3 \\
\hline MBA & $\begin{array}{l}\text { Planning and control } \\
\text { manager }\end{array}$ & Energy & 2 \\
\hline MBA & $\begin{array}{c}\text { Corporate human resources } \\
\text { manager }\end{array}$ & Mining & 2 \\
\hline $\begin{array}{l}\text { Master's in government } \\
\text { and local development }\end{array}$ & $\begin{array}{l}\text { Social and responsibility } \\
\text { manager }\end{array}$ & Mining & 2 \\
\hline MBA & Medical coordinator & Health & 3 \\
\hline
\end{tabular}

Note. Source: Elaborated by the authors.

The questions presented to female executives, as can be seen in the interview guide located in the Appendix, were related to their work histories and the challenges which they faced in their careers in order to arrive at their current positions, specifically addressing the issues of education and work experience, organisational culture, stereotypes, labour networks or social capital, and family responsibilities. Male executives were asked about their perception of the career advancement of their female counterparts and also the challenges they face, especially related to family responsibilities and the promotion of gender equality. A semi-structured approach was employed to facilitate fluent conversation and discussion and to allow for more revealing responses. All of the interviews were conducted face-to-face and lasted between 1 and 2 hours.

\section{Data analysis and validity}

The content of these in-depth interviews was transcribed and analysed using qualitative analysis and we performed open coding (line-by-line analysis to extract codes) and axial coding (joining the codes). To identify the codes and key concepts, interviews were continuously compared with one another until patterns started to emerge. In addition, the literature and research objectives were reviewed each time a key concept was identified. Atlas TI software was used to support this analysis. For example, several phrases from the interviews included, "I have to help my children ...", "I have to take them to 
their extracurricular activities" and "I have to play...". These phrases were combined, and the family responsibilities code emerged.

This study has sought internal validity, external validity and reliability. In order to assure internal validity, Merriam (1998) recommends the use of triangulation, review of the interviews by the people who were interviewed, repeated observations of the event and review of the study by colleagues. For this study, some participants were asked to read the transcripts of their interviews in order to see if the interviews accurately reflected their words and behaviours. External validity refers to the scope of the study's findings in order for them to be generalizable. To that end, Merriam (1998) indicates that generalisation should be left to the readers, as the readers are the ones who must ask themselves how they can apply the study to their own situations. In order to achieve this, a detailed description of the factors, the study context, the data collection process and the analysis have been provided so that the readers have sufficient information to determine if the findings can be transferred. Finally, in order to achieve reliability, an audit trail was used; it consisted of describing in detail how that data were collected (Merriam, 1998), explaining in this way the detailed protocols for the interview guide for both female and male executives.

\section{Results}

The results of the interviews allow identification of four challenges that female executives face regarding their career advancement: family responsibilities, educational attainment and experience, informal networks and social capital, and organizational culture. Also, it is perceived that women's career advancement is slow, perhaps due to the challenges that must be faced.

Among the women executives with children, family responsibilities were perceived as the principal challenge faced in their career advancement. The majority of the interviewees said they work more than 8 hours per day. Several female interviewees had left the sector in which they had been working prior to their current job, mainly due to the highly competitive nature of that sector. They commented that, in Peruvian culture, women are generally responsible for the children and the housework. In this regard, the women reported having to divide their time between family and work and said that it was difficult to know which to prioritise at times. One female executive stated, "My career was a major factor in deciding not to have more children. It was hard to share childrearing with the nanny. I cried a lot the weekend when I heard [my son] calling Eva, [the nanny] who took care of him, 'Mom'”.

In this way, some of the female interviewees had not sought international career opportunities, as they gave priority to their childrearing responsibilities rather than to work. It is important to highlight that several male executives stated that they helped very little with family responsibilities; for example, they provided little help to their children with school homework or extracurricular activities. However, these male interviewees commented that grandparents or nannies could help with childcare and that domestic support services could help with household chores. Most executives, both male and female, said that they have inexpensive domestic support services at home. It is also worth pointing out that some wives of the male interviewees had created their own businesses as a way of harmonising family and work.

It is interesting to note that some of the male interviewees' wives had opted to leave employment. In this sense, one executive manager affirmed, "My wife chose to devote her time to our son; one may say she was professionally frustrated, though in the end, it is a great satisfaction to have well-broughtup children, and it is the best time investment she has made". It is noteworthy that no male executive interviewed opted to take charge of the care of his children (or to take on the principal role in this endeavour) in order to improve the way the family worked or to help his wife's or partner's career, since it is a given in Peruvian culture that childcare is women's work. 
Another challenge for female executives is educational attainment and experience. In this study it can be appreciated that the percentage of women with an MBA is lower than the percentage of men with an MBA. The women interviewees commented that getting a master's degree demands time, expense and effort. In this sense, one female executive said, "I almost got divorced when I studied my MBA because I was not playing with my children, and I was not at home on Saturday". Male executives said that it is very difficult for a woman to obtain an MBA because of her family responsibilities. One male executive added, "In my case, I studied my MBA 2 years ago, and my wife will study one when the children grow up".

Other interviewees believed that the income disparity between genders can cause young families to prioritise the man's career advancement over the woman's because he will have greater growth prospects financially. In this sense, one of the male interviewees stated, "We decided that I would study the master's program and not my wife because we considered the financial prospects". Work experience outside the place of residence, especially on an international level, is a very important factor for career advancement in a global environment. In many cases, international experience is a requirement for obtaining a promotion.

In this sense, a female executive stated that she had to travel 4 days per month to get her promotion. Another female executive said that, in her previous job, she had had to travel 8 weeks out of 10 , which had a tremendous emotional cost; moreover, her husband also travelled for work, and, for this reason, she felt she needed to change her job. Other female executives said that they had to avoid travelling, meaning that their professional experience was only local rather than national or international, which restricted their promotion to only certain positions. Some male executives stated that most organisations do not want to hire women because of the costs incurred when these female employees become pregnant. They went on to say that these pregnancies also limited the female employees' work experience. Moreover, they also said that top-level positions require travel, which many Peruvian women cannot undertake because of their family responsibilities.

Another challenge facing Peruvian female executives is developing informal networks and social capital. Networks increase their members' visibility to other key people and help develop business opportunities. As one male interviewee observed, "Informal networks help men to get into businesses". Most Peruvian organisations organise football championships to consolidate and strengthen the relationships within teams and between the departments of the company. The downside of these championships is that only men play football in Peru. Professional women with family responsibilities generally participate in social activities during working hours only. The men interviewed agreed that women should not participate in gatherings outside work for cultural reasons. In this sense, another male interviewee said, "It is still uncommon for a woman with a family to use her free time participating in informal gatherings, [...] but they participate in birthday celebrations during working hours and [use] social media".

Another challenge that female executives face regarding their career advancement is organisational culture. Most female interviewees indicated that the behaviour of most organisations is based on gender stereotypes, characterising women as dependent, indecisive people who are sensitive and who must take care of their children. In contrast, some male executives observed that since the financial crisis of the 1990s, women have had to work, either in salaried positions or in their own businesses, to help their family budgets. They also mentioned that gender stereotypes in their organisations have been declining steadily. However, for many organisations, hiring a man instead of a woman is perceived as less of a risk for the organisation. One of the interviewees remarked, "Women are at a disadvantage beginning at the recruiting stage because a company may consider a woman riskier because she has to balance home, family and, at a certain point, pregnancy benefits".

The unmarried female interviewees without children commented that they face some stereotypes in their organisations, such as the mind-set that women should be mothers, without taking into consideration that not all women aspire to motherhood. They also confront the view that managerial positions should be occupied by men, since women do not have leadership skills, and the perspective that women who obtain executive or managerial positions do so more thanks to their sensuality than to 
their professional skills. The interviewees said these stereotypes have made their own career advancements more difficult.

\section{Discussion and Conclusions}

This study shows that the four global challenges are also present in Peru, with family responsibilities being the one that is most crucial to the careers of women executives, as this study's findings coincide with those of other studies conducted in other parts of the world, such as those by Tharenou, Latimer and Conroy, 1994; Hewlett, 2002; O'Neil and Bilimoria, 2005; Lyonette and Crompton, 2008; and Bass, 2015, although with certain distinctive features.

Peruvian female executives who are mothers develop their careers in the midst of traditional surroundings with few alternatives to help them reach a work-life balance which permits them to articulate their familial and personal roles, since although there are organisations which have implemented measures and developed practices along these lines, flexibility regarding work hours and spaces is still far from being a common characteristic of the Peruvian business world (IPSOS Perú, 2014). It must be added that telework, although regulated by national law, is still a relatively new and less frequently implemented practice and, on the other hand, as some have said (Kogan, 2014), it does not tend to be approved of in Peruvian society.

Peruvian male executives, due to their country's culture, consider limitations on women's career advancement, especially family responsibilities, to be something natural and normal. For example, many Peruvian women with young children stop working in order to dedicate themselves to their children; in this sense, men recognise that they could feel frustrated regarding their career advancement, but in reality, according to the male executives, this frustration is compensated for by the fact that they are raising their children well. Female executives have accepted these restrictions to their career advancement and have adapted to this situation with initiatives such as opening their own small businesses.

Indeed, being an executive in Peru is an extremely demanding task, maybe more so than it is in other parts of the world. In a study of 800 Peruvian executives (men and women), more than half said they work more than fifty hours a week on average, that is, more than ten hours per day Monday to Friday. As many as $76 \%$ said they review work email or work on weekends, and three out of four feel they have a heavy or very heavy workload; two-thirds report they work more than eight hours a day but that it is not enough, and 55\% (62\% for women) feel dissatisfied or very dissatisfied with the amount of time dedicated to their family or personal lives: on the whole between two to three hours each day (IPSOS Perú, 2014). These data are very critical and revealing about the demands placed on Peruvian executives.

It must also be emphasised that, for both male and female executives, the partner who has chosen to put off his or her career if it was necessary to attend to family priorities (childcare, caretaking for elderly family members, etc.) was the woman. The repercussion was a lack of professional experience for the woman in these situations. This finding coincides with that of a study conducted by Tharenou et al. (1994), in which women had less professional experience when compared to men due to their childcare responsibilities.

The results of this study furthermore reveal that the majority of the women interviewed had changed sectors, which could be a trend in the career management of Peruvian female executives: a trend to be self-directed as a function of their own needs and expectations. This would indicate that the women desire to be incorporated into other career models, such as the women's career model (O'Neil $\&$ Bilimoria, 2005), through human resource policies. These findings are consistent with those reported by several authors (Baruch, 2006; Baruch \& Reis, 2015; Broadbridge, 2015) with regard to the continued 
presence and majority practice of the traditional models in the business world, since, although the new models are increasingly present, their presence is still limited.

The study also shows that women executives have difficulty obtaining postgraduate studies, especially MBA degrees, a finding which coincides with the findings of other studies (Cheung \& Halpern, 2010; Hoobler et al., 2014; Morley, 2014). Furthermore, the men interviewed maintained that starting MBA studies is a priority for them in order to reach higher professional and financial goals in the future. At the same time, the lower number of women with doctorates in Peru, in comparison with the number of men with doctorates, demonstrates the fact that the greater time investments required by these studies means lower possibilities for women to start and finish them.

It should be emphasised that very few of the female executives interviewed have stayed in positions that called for work-related travel. This is in accordance with the low percentage of women who have been assigned to international posts (Brookfield Global Relocation Services, 2016) and thus have lower levels of professional experience.

Additionally, there is little evidence of clear and structured initiatives among companies to promote the development of informal networks and social capital during working hours. Women executives have limited time due to their family responsibilities, which means that women use social networks less than men do and that the time they interact on them is in the morning, when their children are at school. This coincides with Wirth's study (2001), which found that women executives tend to establish fewer and smaller networks of contacts than men do. Internet-based applications could be an alternative to foment the use of networking among women; however, according to INEI (2017b), men's use of the Internet on a daily basis is greater than that of women.

Another important finding is that the national culture and the organisational cultures present complications that exacerbate the challenge of family responsibilities that Peruvian female executives must face when attempting to advance in their careers. Beyond the fact that Peru as a country possesses an abundance of prevailing gender stereotypes as the female interviewees commented, specifically, it is still a conservative society in which the family has a special value, as women are assigned the role of family caretakers (Anderson, 2011). Indeed, Peruvian women grow up and develop in a culture that considers marriage and family of central import to society. In accordance with Kumra and Vinnicombe (2008), this could cause Peruvian women to perceive a career as an executive to be more of a challenge than their male counterparts do. This context has given rise to structural barriers on the societal level that influence the organisational level.

The limitations to career advancement that women face are recognised and accepted by men, but men do not question these limitations, nor do they have an attitude of change. Worse still, women accept this situation and deal with it, leaving employment or looking for more flexible jobs. Peruvian organisations still carry out only limited structured efforts to help women overcome challenges regarding their career paths. These organisations lack sufficient gender policies and maintain traditional practices that are immersed in their country's culture.

Finally, globally, slow progress is being achieved with regards to women's career advancement (Burke \& Richardsen, 2017), perhaps due to the challenges that must be faced. However, Carli and Eagly (2016) say that, despite these labyrinthine challenges, women can still advance to high levels of leadership. In countries like Peru, there is still a long way to go in order to catch up to the level of the most advanced nations in gender equality.

\section{Implications}

In Peru, it is necessary for the government to implement policies which encourage gender equality, such as educational policies and labour laws, and award prizes or other forms of recognition to organisations that promote gender equality. 
Also, it is important that organisations put emphasis on creating a culture of gender equity, expressed in their mission statements, philosophy and even symbols. Likewise, human resource policies and processes which lead to gender equity must be practically implemented. For example, some jobs could be redesigned to implement telework and flexible hours; performance evaluation could focus not only on attendance at the workplace but also on the measurement of results; horizontal promotion approaches, focused on people, could be put in place; and standards which punish gender stereotypes, and which guide equitable behaviour by collaborators could be established. Other practices which could help include the development of female mentoring networks in which successful women, in addition to acting as models to follow, support other female executives in becoming more proactive and to clearly define their personal and professional goals and career planning in order to avoid work-family conflict.

\section{Limitations and future research}

In spite of this study's results and discussion, it includes some limitations that should be addressed in future research. The first shortcoming is that, because of the filters for the selection of the sample, participants were obtained from a wide variety of sectors, numerous different professions and heterogeneous marital and parental statuses. In future research, it would be convenient to concentrate on samples by sector or by profession in order to investigate their distinctive features in greater depth; this would, in turn, permit the subsequent identification of the similarities and differences of the challenges that female executives in Peru and other countries face. The second limitation is that the challenges addressed in this research study are challenges at the organisational level; future studies could focus on exploring other challenges, such as individual features which may affect the development of women.

Issues in gender and the career development of female executives in Peru should be studied in depth, taking into consideration not just level and years of education but also age, generational influence, academic field and study-abroad experience.

\section{Contributions}

1st author: concept, design, writing, analysis and discussion of results.

2nd author: concept, design and analysis.

\section{References}

Acker, J. (2006). Inequality regimes: Gender, class, and race in organizations. Gender and Society, 20(4), 441-464. https://doi.org/10.1177/0891243206289499

Anderson, J. (2011). Responsabilidades por compartir: Conciliación trabajo-familia en Perú. Santiago, Chile: Organización Internacional del Trabajo.

Andina Agencia Peruana de Noticias. (2018, marzo). Peru: Lima Stock Exchange joins gender equality celebrations with bell ringing. Retrieved from https://andina.pe/agencia/noticia-peru-lima-stockexchange-joins-gender-equality-celebrations-with-bell-ringing-702502.aspx

Baruch, Y. (2004). Transforming careers: From linear to multidirectional career paths: organisational and individual perspectives. Career Development International, $9(1), \quad 58-73$. https://doi.org/10.1108/13620430410518147 
Baruch, Y. (2006). Career development in organisations and beyond: Balancing traditional and contemporary viewpoints. Human Resource Management Review, 16(2), 125-138. https://doi.org/10.1016/j.hrmr.2006.03.002

Baruch, Y., \& Reis, C. (2015). Global career challenges for women crossing international borders. In A. M. Broadbridge, \& S. L. Fielden (Eds.), Handbook of gendered careers in management: Getting in, getting on, getting out (pp. 341-356). UK: E. E. Publishing.

Bass, B. C. (2015). Preparing for parenthood? Gender, aspirations, and the reproduction of labor market inequality. Gender \& Society, 29(3), 362-385. https://doi.org/10.1177\%2F0891243214546936

Betz, N., \& Fitzgerald, L. (1987). The career psychology of women. New York, NY: Academic Press.

Blondet, C., \& Montero, C. (1994). La situación de la mujer en el Perú, 1980-1994. Retrieved from http://repositorio.iep.org.pe/handle/IEP/816

Broadbridge, A. (2008). Senior careers in retailing: An exploration of male and female executives' career facilitators and barriers. Gender in Management: An International Journal, 23(1), 11-35. https://doi.org/10.1108/17542410810849105

Broadbridge, A. (2015). How some women achieve success. In A. M. Broadbridge, \& S. L. Fielden (Eds.), Handbook of gendered careers in management: Getting in, getting on, getting out (pp. 258-274). UK: E. E. Publishing.

Brookfield Global Relocation Services. (2016). Breakthrough to the future of global talent mobility 2016 Global mobility trends survey. Woodridge, IL: Author.

Burke, R., \& Richardsen, A. (2017). Women in management worldwide. New York: Routledge.

Cabrera, E. (2007). Opting out and opting in: Understanding the complexities of women's career transitions. Career Development International, 12(3), 218-237. https://doi.org/10.1108/13620430710745872

Carli, L., \& Eagly, A. (2016). Women face a labyrinth: An examination of metaphors for women leaders. Gender in Management: An International Journal, 31(8), 514-527. https://doi.org/10.1108/gm02-2015-0007

Cheung, F. M., \& Halpern, D. F. (2010). Women at the top: Powerful leaders define success as work+ family in a culture of gender. American Psychologist, 65(3), 182-193. https://doi.org/10.1037/a0017309

Defillippi, R. J., \& Arthur, M. B. (1994). The boundaryless career: A competency-based prospective. Journal of Organisational Behavior, 15(4), 307-324. https://doi.org/10.1002/job.4030150403

De Pater, I. E., Van Vianen, A. E. M., \& Bechtoldt, M. N. (2010). Gender differences in job challenge: A matter of task allocation. Gender, Work \& Organisation, 17(4), 433-453. https://doi.org/10.1111/j.1468-0432.2009.00477.x

Duberley, J., Carmichael, F., \& Szmigin, I. (2014). Exploring women's retirement: Continuity, context and career transition. Gender, Work \& Organization, 21(1), 71-90. https://doi.org/10.1111/gwao.12013

Eagly, A., \& Carli, L. L. (2007). Women and the labyrinth. Harvard Business Review, 85(9), 62-71. Retrieved from https://hbr.org/2007/09/women-and-the-labyrinth-of-leadership

Evetts, J. (2000). Analyzing change in women's careers: Culture, structure and action dimensions. Gender, Work and Organisation, 7(1), 57-67. https://doi.org/10.1111/1468-0432.00093 
Festing, M., Kornau, A., \& Schäfer, L. (2015). Think talent - think male? A comparative case study analysis of gender inclusion in talent management practices in the German media industry. The International Journal of Human Resource Management, 26(6), 707-732. https://doi.org/10.1080/09585192.2014.934895

Freyre, M., \& López, E. (2011). Brechas de género en la distribución del tiempo. Retrieved from https://www.mimp.gob.pe/files/direcciones/dgignd/publicaciones/Brechas-de-genero-en-el-Usodel-Tiempo.pdf

Greenhaus, J., \& Parasuraman, S. (1993). Job performance attributions and career advancement prospects: An examination of gender and race effects. Organisational Behaviour and Human Decision Processes, 55(2), 273-297. https://doi.org/10.1006/obhd.1993.1034

Hall, D. T. (1976). Careers in organisations. Pacific Palisades, CA: Goodyear Pub. Co.

Hall, D. T. (2002). Careers in and out of organizations. Thousand Oaks, CA: Sage.

Hall, D. T., \& Moss, J. E. (1999). The new protean career contract: Helping organisations and employees adapt. Organisational Dynamics, 26(3), 22-37. https://doi.org/10.1016/s0090-2616(98)90012-2

Heller, L. (2011). Mujeres en la cu-mbre corporativa. Revista del Centro de Estudios de Sociología del Trabajo, 3, 68-96. $\quad$ Retrieved from http://bibliotecadigital.econ.uba.ar/?c=revcesot\&a=d\&d=revcesot_n3_03

Herman, C. (2015). Rebooting and rerouting: Women's articulations of frayed careers in science, engineering and technology professions. Gender, Work \& Organisation, 22(4), 324-338. https://doi.org/10.1111/gwao.12088

Hewlett, S. A. (2002). Executive women and the myth of having it all. Harvard Business Review, 80(4), 66-73. Retrieved from https://hbr.org/2002/04/executive-women-and-the-myth-of-having-it-all

Hoobler, J. M., Lemmon, G., \& Wayne, S. J. (2014). Women's managerial aspirations: An organizational development perspective. Journal of Management, 40(3), 703-730. https://doi.org/10.1177/0149206311426911

Ibarra, H. (1992). Homophily and differential returns: Sex differences in network structure and access in an advertising firm. Administrative Science Quarterly, 37(3), 422-447. https://doi.org/10.2307/2393451

Instituto Nacional de Estadística e Informática. (1972). Séptimo censo nacional de población. Lima, Peru: Biblioteca Institucional del INEI.

Instituto Nacional de Estadística e Informática. (2011, mayo). Encuesta nacional de uso del tiempo 2010 - Principales resultados. Retrieved from http://www.unfpa.org.pe/publicaciones/publicacionesperu/MIMDES-INEI-Encuesta-NacionalUso-Tiempo.pdf

Instituto Nacional de Estadística e Informática. (2015a, marzo). En el Perú 15 millones de mujeres celebran su día [Nota de prensa no. 030]. Retrieved from https://www.inei.gob.pe/media/MenuRecursivo/noticias/nota-de-prensa-n030-2015-inei.pdf

Instituto Nacional de Estadística e Informática. (2015b). Perú: Indicadores de educación por departamentos 2004-2014. Retrieved from https://www.inei.gob.pe/media/MenuRecursivo/publicaciones_digitales/Est/Lib1293/libro.pdf

Instituto Nacional de Estadística e Informática. (2016). Perú: Encuesta demográfica y de salud familiar 2016 - Nacional y regional. Retrieved from https://www.inei.gob.pe/media/MenuRecursivo/publicaciones_digitales/Est/Lib1433/index.html 
Instituto Nacional de Estadística e Informática. (2017a, mayo). Más del 60\% de las madres del país trabajan [Notas de prensa]. Retrieved from https://www.inei.gob.pe/prensa/noticias/mas-del-60de-las-madres-del-pais-trabajan-9714/

Instituto Nacional de Estadística e Informática. (2017b). Estadísticas con enfoque de género (Informe técnico no. 03). Retrieved from http://www.inei.gob.pe/media/MenuRecursivo/boletines/03informe-tecnico-n03_estadisticas-genero-abr-jun2017.pdf

International Labour Organization. (2015). La mujer en la gestión empresarial: Cobrando impulso. Retrieved from https://www.ilo.org/wcmsp5/groups/public/---dgreports/---dcomm/--publ/documents/publication/wcms_335674.pdf

IPSOS Perú. (2014). En búsqueda del equilibrio: Primer estudio sobre la conciliación vida trabajo en los ejecutivos peruanos. Retrieved from https://es.scribd.com/document/260159592/En-Buscade-Equilibrio

Joshi, A., Neely, B., Emrich, C., Griffiths, D., \& George, G. (2015). Gender research in AMJ: An overview of five decades of empirical research and calls to action thematic issue on gender in management research. Academy of Management Journal, 58(5), 1459-1475. https://doi.org/10.5465/amj.2015.4011

Kelly, E. L., Ammons, S. K., Chermack, K., \& Moen, P. (2010). Gendered challenge, gendered response confronting the ideal worker norm in a white-collar organisation. Gender and Society, 24(3), 281303. https://doi.org/10.1177/0891243210372073

Khapova, S., Brisoce, J., \& Dickman, M. (2016). Career in cross cultural perspective. In J. P. Briscoe, D. T. Hall, \& W. Mayrhofer (Eds.), Careers around the world: Individual and contextual perspectives (pp. 15-38). New York: Routledge.

Kogan, L., Fuchs, R. M., \& Lay, P. (2013). No pero sí: Discriminación en empresas de Lima Metropolitana. Lima, Peru: Universidad del Pacífico.

Kogan, L. (2014). "No sé cómo lo hacemos, pero es muy sacrificado": Mujeres profesionales en el ámbito de la gran empresa limeña. In S. Vargas (Comp.), Bajo el radar de Sofía: Oportunidades y barreras de las profesionales en el Perú (pp. 108-116). Lima, Peru: IEP Instituto de Estudios Peruanos.

Kumra, S., \& Vinnicombe, S. (2008). A study of the promotion to partner process in a professional services firm: How women are disadvantaged. British Journal of Management, 19(s1), 65-74. https://doi.org/10.1111/j.1467-8551.2008.00572.x

Kumra, S., \& Vinnicombe, S. (2010). Impressing for success: A gendered analysis of a key social capital accumulation strategy. Gender, Work \& Organization, 17(5), 521-546. https://doi.org/10.1111/j.1468-0432.2010.00521.x

LeCompte, M. D., \& Schensul, J. J. (2010). Designing and conducting ethnographic research (Vol. 1). Lanham, MD: Rowman \& Littlefield Publishers, Inc.

Lyonette, C., \& Crompton, R. (2008). The only way is up? An examination of women's "underachievement" in the accountancy profession in the UK. Gender in Management: An International Journal, 23(7), 506-521. https://doi.org/10.1108/17542410810908857

Mainiero, L. A., \& Sullivan, S. E. (2005). Kaleidoscope careers: An alternate explanation for the "optout" revolution. Academy of Management Perspectives, 19(1), 106-123. https://doi.org/10.5465/ame.2005.15841962

Marshall, J. (1995). Gender and management: A critical review of research. British Journal of Management, 6(s1), 53-60. https://doi.org/10.1111/j.1467-8551.1995.tb00138.x 
Mavin, S. (2001). Women's career in theory and practice: Time for change? Women in Management Review, 16(4), 183-192. https://doi.org/10.1108/09649420110392163

Merriam, S. (1998). Qualitative research and case study applications in education. San Francisco: Jossey-Bass Publishers.

Metz, I. (2005). Advancing the careers of women with children. Career Development International, 10(3), 228-245. https://doi.org/10.1108/13620430510598346

Ministerio de Trabajo y Promoción del Empleo. (2006). Informe anual 2005: La mujer en el mercado laboral peruano. Retrieved from http://www.mintra.gob.pe/archivos/file/estadisticas/peel/documento_mujer/inf_anual_mujer_20 05.pdf

Ministerio de Trabajo y Promoción del Empleo. (n.d.a). Perú: Ingreso laboral promedio mensual de la PEA ocupada según sexo y categoría oupacional 2004-2016. Retrieved from http://www2.trabajo.gob.pe/promocion-del-empleo-y-autoempleo/informacion-del-mercado-detrabajo/peru-total-por-sexo/

Ministerio de Trabajo y Promoción del Empleo. (n.d.b). Perú: Ingreso laboral promedio mensual de la PEA ocupada según sexo y nivel educativo alcanzado, 2004 -2016. Retrieved from http://www2.trabajo.gob.pe/promocion-del-empleo-y-autoempleo/informacion-del-mercado-detrabajo/peru-total-por-sexo/

Morley, L. (2014). Lost leaders: Women in the global academy. Higher Education Research and Development, 33(1), 114-128. https://doi.org/10.1080/07294360.2013.864611

Mota-Santos, C., Tanure, B., \& Carvalho, A., Neto. (2014). Brazilian executive women: The glass ceiling in question. Journal Administration in Dialogue, 16(3), 56-75. https://doi.org/10.20946/rad.v16i3.13791

O'Neil, D. A., \& Bilimoria, D. (2005). Women's career development phases: Idealism, endurance, and $\begin{array}{llll}\text { reinvention. } \quad \text { Career Development International, 10(3), } & \text { 168-189. }\end{array}$ https://doi.org/10.1108/13620430510598300

O’Neil, D. A., Hopkins, M. M., \& Sullivan, S. E. (2011). Do women's networks help advance women's careers? Differences in perceptions of female workers and top leadership. Career Development International, 16(7), 733-754. https://doi.org/10.1108/13620431111187317

Powell, G., Butterfield, A., \& Parent, J. (2002). Gender and managerial stereotypes: Have the times changed? Journal of Management, 28(2), 177-193. https://doi.org/10.1016/s01492063(01)00136-2

Pringle, J., \& Mallon, M. (2003). Challenges for the boundaryless career odyssey. International Journal of Human Resource Management, 14(5), 839-853. https://doi.org/10.1080/0958519032000080839

Ragins, B. R., \& Sundstrom, E. (1989). Gender and power in organisations: A longitudinal perspective. Psychological Bulletin, 105(1), 51-88. https://doi.org/10.1037//0033-2909.105.1.51

Schein, E. H. (1978). Career dynamics: Matching individual and organisational needs. Reading Mass: Addison Wesley Pub. Co.

Still, L., \& Timms, W. (1998). Career barriers and the older woman manager. Women in Management Review, 13(4), 143-155. https://doi.org/10.1108/09649429810219754

Stone, P. (2007). Opting out? Why women really quit careers and head home. Berkeley, CA: University of California Press. 
Tharenou, P. (1997). Explanations of managerial career advancement. Australian Psychologist, 32(1), 19-28. https://doi.org/10.1080/00050069708259614

Tharenou, P., Latimer, S., \& Conroy, D. (1994). How do you make it to the top? An examination of influences on women's and men's managerial advancement. Academy of Management Journal, 37(4), 899-931. https://doi.org/10.5465/256604

Unite, J., Parry, E., Briscoe, J., \& Chudzikowski, K. (2016). Careers and age: Career success for older and younger. In J. P. Briscoe, D. T. Hall, \& W. Mayrhofer (Eds.), Careers around the world: Individual and contextual perspectives (pp. 118-144). New York: Routledge.

Vance, C. M., \& McNulty, Y. (2014). Why and how women and men acquire global career experience: A study of American expatriates in Europe. International Studies of Management \& Organization, 44(2), 34-54. https://doi.org/10.2753/imo0020-8825440202

Warren, T., \& Walters, P. (1998). Appraising a dichotomy: A review of 'part-time/full time' in the study of women's employment in Britain. Gender, Work and Organisation, 5(2), 102-106. https://doi.org/10.1111/1468-0432.00049

Wirth, L. (2001). Breaking through the glass ceiling: Women in management. Geneva: International Labour Office.

World Bank. (2018). Perú: Overview. Retrieved from http://www.worldbank.org/en/country/peru/overview

World Economic Forum. (2016). The global gender gap report 2016. Retrieved June 2, 2017, from http://www3.weforum.org/docs/GGGR16/WEF_Global_Gender_Gap_Report_2016.pdf

Zabludovsky, G. (2007). México: Mujeres en cargos de dirección del sector privado. Revista Latinoamericana de Administración, 38(1), 9-26. Retrieved from http://www.redalyc.org/articulo.oa

\section{Authors}

Kety Jáuregui

Universidad ESAN, Alonso de Molina, 1652, Lima, Peru. E-mail address: kjauregui@esan.edu.pe. http://orcid.org/0000-00019636-5183

Mariella Olivos

Universidad ESAN, Alonso de Molina, 1652, Lima, Peru. E-mail address: molivos@ esan.edu.pe. https://orcid.org/0000-00033044-1686 


\section{APPENDIX}

\section{Interview guide}

\section{Female executives}

Q1 Talk to me in a detailed manner about your work history and professional development.

Q2 Explain the challenges you have faced in your career advancement to reach your current position.

Q3 Elaborate on your explanation of the four main challenges:

Family responsibilities,

Education and work experience,

Organisational culture and stereotypes and

Informal networks and social capital.*

* In case these challenges were not explained in response to question 2.

\section{Male executives}

Q1 Comment on your perceptions of the professional development and advancement of your female colleagues.

Q2 Explain your perceptions of the challenges women face in their career advancement.

Q3 Elaborate on your explanation of the following:

Gender equity

Family responsibilities,

Education and work experience,

Organisational culture and stereotypes and

Informal networks and social capital.*

* In case these items were not explained in response to question 2. 